\title{
7 \\ WOMEN AND THE BIOGRAPHIES OF NATIONS: \\ THE BIOGRAPHICAL DICTIONARY OF SCOTTISH WOMEN
}

\author{
ELIZABETH EWAN
}

While national biographical dictionaries aim to present a nation's past, they are also very much creations of that nation's present. The Biographical Dictionary of Scottish Women (The BDSW), published in 2006, is no exception. ${ }^{1}$ The first edition was conceived at a time (2001) when Scotland had just recently reconvened its own parliament after a hiatus of nearly 300 years, gaining new powers of self-governance. In the wake of rising self-confidence in the country's future, the writing of new national histories, as well as handbooks and companions, flourished. A revised and expanded volume, The New Biographical Dictionary of Scottish Women (The New BDSW), was commissioned in late 2015, on the heels of the 2014 independence referendum. Moreover, it was compiled in the midst of the repercussions of the 2016 Brexit vote which may yet lead to the breakup of the United Kingdom, given that a majority in Scotland voted

1 Elizabeth Ewan, Sue Innes, Siân Reynolds, and Rose Pipes, eds, The Biographical Dictionary of Scottish Women: From the Earliest Times to 2004 (Edinburgh: Edinburgh University Press, 2006). A paperback edition, with corrections, was published in 2007. For more detailed discussion on the work on the first edition of the dictionary, see Sue Innes, 'Reputations and Remembering: Work on the First Biographical Dictionary of Scottish Women', Etudes Écossaises 9 (2003-4): 11-26. 
to remain in the European Union. On a more positive note, the new volume has also taken shape in a country where, until recently, the leaders of all three main political parties, including the first minister, were women.

This chapter looks at the roles biographical dictionaries of women can play in biographies of nations, taking Scotland as its example. It examines the context in which The Biographical Dictionary of Scottish Women was developed, the influence it has had to date on Scotland's approach to its history, and the lessons learned and new issues arising during work on The New BDSW. At the conference on which this volume is based, it became clear that there are issues in common faced by all editors of national biographical dictionaries, but also that there are contributions that can be made to the debates by those involved in what might be considered more specialist versions of such dictionaries. ${ }^{2}$

In the later twentieth and early twenty-first centuries, new biographical dictionaries of women have been published in several countries, alongside national biographical dictionary projects. Among these are The New Zealand Book of Women/Ko Kui Ma Te Kaupapa (1991), Women of Ireland: A Biographic Dictionary (1996), and Notable American Women (19712004). ${ }^{3}$ The situation in Scotland has been somewhat different. Because it has not been an independent country since the Union of the Parliaments in 1707, its most recent 'biography of the nation' has been compiled as part of the larger British work, the Oxford Dictionary of National Biography $(O D N B)$. As a result, the work of professional historians has been directed to the $O D N B$ rather than to a separate Scottish biographical dictionary. As a distinct group, Scottish women have tended to be subsumed under the larger category 'British', appearing with English, Irish, and Welsh women in The Europa Biographical Dictionary of British Women (1983) and its revised edition A Historical Dictionary of British Women (2003). ${ }^{4}$

\footnotetext{
2 See also the chapters by Ware and Konishi in this volume.

3 Charlotte Macdonald, Merimeri Penfold, and Bridget Williams, eds, The New Zealand Book of Women/Ko Kui Ma Te Kaupapa (Wellington: Bridget Williams Books, 1991). doi.org/10.7810/ 9780908912049; Kit Ó Céirín and Cyril Ó Céirín, Women of Ireland: A Biographic Dictionary (Kinvara: Tír Eolas, 1996); Edward T. James, Janet Wilson James, and Paul S. Boyer, eds, Notable American Women, 1607-1950: A Biographical Dictionary, 3 vols (Cambridge, MA: Harvard University Press, 1971); Barbara Sicherman and Carol Hurd Green, eds, Notable American Women, The Modern Period: A Biographical Dictionary (Cambridge, MA: Harvard University Press, 1980); Susan Ware and Stacy Braukman, eds, Notable American Women: A Biographical Dictionary, Completing the Twentieth Century (Cambridge, MA: Harvard University Press, 2004).

4 Anne Crawford, ed., The Europa Biographical Dictionary of British Women (London: Europa Publications, 1983); Cathy Hartley, ed., A Historical Dictionary of British Women (London and New York: Europa Publications Ltd, 2003).
} 
The Biographical Dictionary of Scottish Women, then, is the only multiauthored twenty-first-century biographical dictionary which focuses on the lives of Scottish people over two millennia and the entire country.

No biographical dictionary is truly a neutral work of reference. By its very nature it cannot be so, as principles of selection and the areas which are emphasised in individual entries shape its perspective. Nineteenthcentury national biographical dictionaries tended to develop out of nationalism, with patriotic intent, celebrating the deeds of the eminent men (and occasionally women) of the nation. ${ }^{5}$ The British Dictionary of National Biography, begun in the late nineteenth century, had a wider mandate, including those who made their names abroad such as 'the early settlers of America... [and those] of less widely acknowledged importance'. ${ }^{6}$ Many of the dictionaries compiled in the second half of the twentieth century and the early twenty-first century, especially with the rise of social history and women's history, broadened their principles of inclusion still further to include those previously neglected or marginalised in national histories. For example, the editors of the Dictionary of Irish Biography (2009) commented, 'The dramatic growth in research and publication in women's history has substantially changed the agenda for a work such as this'. ${ }^{7}$ The Dictionary of New Zealand Biography, first published in 1990, acknowledged the importance of including traditionally underrepresented groups, including Māori people and women. ${ }^{8}$ Who is included as being part of the 'nation' has tended to broaden as well, with some subjects being entered in dictionaries who never set foot in the country but who are deemed to have had a connection with or influence on it. ${ }^{9}$ The issue of 'representative' entries has also come to the fore, as some subjects have

5 Keith Thomas, Changing Conceptions of National Biography: The Oxford DNB in Historical Perspective (Cambridge: Cambridge University Press, 2005), 9-17. doi.org/10.1017/ CBO9780511497582.

6 Sidney Lee, 'The Dictionary of National Biography. A Statistical Account', in Dictionary of National Biography, eds Leslie Stephen and Sidney Lee (London: Smith, Elders \& Co, 1908), vol. 1, x. 7 James McGuire and James Quinn, 'Introduction', in Dictionary of Irish Biography, eds James McGuire and James Quinn, vol. 1, A-Burchill (Cambridge: Cambridge University Press, 2009), xxi. 8 W. H. Oliver 'Introduction', in Dictionary of New Zealand Biography, ed. W. H. Oliver, vol. 1, 1769-1869 (Wellington: Allen and Unwin, 1990), viii-ix.

9 Thomas, Changing Conceptions of National Biography, provides a detailed examination of these developments. 
been chosen not so much for what they had done but for how they were representative examples of a particular group in society. ${ }^{10}$ All of these issues have influenced the character of The BDSW.

One aspect which has distinguished biographical dictionaries of women from larger national ones has been the primary purpose of their originators. Many, if not most, early national dictionaries celebrated the achievements of the great figures in a nation's history, often drawing on a wealth of previous research. In general, women's biographical dictionaries have been motivated more by the goals of discovery and recovery, seeking out those who have been neglected in the nation's story in the past or bringing back to attention those who were well-known at earlier periods but who have disappeared from popular consciousness. For a few subjects, dictionaries have been able to draw on early research from the nineteenth and early twentieth centuries on 'women worthies', and in some countries such as the United States of America, increasing numbers of biographies of individual women, but for many if not the majority of subjects, the entry in the biographical dictionary is the first public recognition of a woman's historical standing. Nineteenth-century national biographical dictionaries often had a moral purpose as well, to inspire the citizens by examples of the great and virtuous deeds of national heroes. Women's biographical dictionaries, the product of a rather different historical age, have rarely focused on such a goal, aiming instead to demonstrate the great variety of women's lives and experiences and not shying away from illustrating the bad as well as the good. For women's and gender historians, there is also a pressing need to shatter the essentialism which is expressed in the use of 'woman' as a category. ${ }^{11}$

10 Oliver, 'Introduction', vii; Melanie Nolan, “Insufficiently Engineered”: A Dictionary to Stand the Test of Time', in The ADB's Story, eds Melanie Nolan and Christine Fernon (Canberra: ANU E Press, 2013), 22-23. doi.org/10.22459/ADBS.10.2013.01. Some other dictionaries, while greatly broadening their scope beyond the elite, have explicitly chosen not to include 'relatively obscure persons as representatives of "ordinary" lives", McGuire and Quinn, 'Introduction', xxi.

11 Elizabeth Ewan, Sue Innes, Siân Reynolds, and Rose Pipes, 'Introduction', in The Biographical Dictionary of Scottish Women: From the Earliest Times to 2004, eds Elizabeth Ewan, Sue Innes, Siân Reynolds, and Rose Pipes (Edinburgh: Edinburgh University Press, 2006), xxvii. 


\section{Compiling a Biographical Dictionary of Women in Scotland}

Why was The $B D S W$ created? As mentioned above, the creation of the Scottish Parliament in 1999 encouraged new efforts to examine the country's past as a whole, including the commissioning of a number of multivolume national histories. In what may have been serendipity or perhaps as a natural result of this new enthusiasm for the nation's history, the Scottish Women's History Network (since 2005, Women's History Scotland) held a meeting in 2001 to discuss ways forward for women's history in Scotland in the new millennium. There was a general recognition that the history of women had made very little headway in being incorporated into mainstream Scottish history, particularly the latest political history of the sort that was being encouraged by the recent political events. ${ }^{12}$ In the 1990 s the Scottish historical profession began to take stock of the state of the field, with a conference on 'The State of Scottish History' held in 1993 and a special issue of the Scottish Historical Review devoted to the question in 1997. In neither of these did women's history have much of a presence. ${ }^{13}$ There were a number of reasons for this, but among them were a general lack of awareness of what research had been done and a belief that the sources for such a study were lacking. ${ }^{14}$

One reason why Scottish women's history had not made much impact on the historical field at large as of 2001 is that women's history and gender history had a late start in Scotland compared to many other countries. They really only developed any strength in the 1990s, although early works and calls for more began to appear in the 1980s. ${ }^{15}$ Most works in the field of gender history postdate 2000. Moreover, to some extent Scottish women have been doubly marginalised, largely ignored in Scottish history because of their sex, and in British history because of

12 Esther Breitenbach, “Curiously Rare”: Scottish Women in History', Scottish Affairs 18 (1997): 81-94. doi.org/10.3366/scot.1997.0010.

13 For discussion of these historiographical reviews, see Jane McDermid, 'No Longer Curiously Rare, But Just Within Bounds', Women's History Review 20, no. 3 (2010): 389-402. doi.org/10.1080 /09612025.2010.509152.

14 Ian Johnston, 'Writing Women Back into History Books', Scotsman, 19 January 2005, 36.

15 See discussion in Lynn Abrams, 'Introduction: Gendering the Agenda', in Gender in Scottish History Since 1700, eds Lynn Abrams, Eleanor Gordon, Deborah Simonton, and Eileen Janes Yeo (Edinburgh: Edinburgh University Press, 2006), 1-16. doi.org/10.3366/edinburgh/9780748617609.003.0001. For work on women's history in Scotland, see the online bibliography at WISH (Women in Scottish History): 'Bibliography of Women in Scottish History', accessed 10 December 2016, womeninscottishhistory.org/wish-database/?page=bibliography. 
their nationality. ${ }^{16}$ Scottish women, like Welsh and Irish women, have been included in the larger undifferentiated category of British women, including in works such as A Historical Dictionary of British Women, and are not explicitly identified as Scottish, as this is not central to the books' purposes. ${ }^{17}$ The majority of works on British history, although not all, deal primarily with English history with only a little, if any, attention paid to Scotland, Wales, and/or Ireland. This is starting to change, however, and certainly the Oxford Dictionary of National Biography has led by example, giving strong coverage to Scotland, although naturally this is interwoven with the much greater number of entries on figures who lived south of the border.

Out of the 2001 meeting came a proposal for a biographical dictionary of Scottish women. Several members were at the time contributing to the $O D N B$ and had already undertaken some biographical research on individual women. One of the major goals of The $B D S W$ project was to demonstrate the great potential for future research by illustrating the richness of the existing sources. Even more importantly, the project sought to demonstrate how women cannot be left out of a nation's history if a true biography of a nation is to be produced. Accompanying the dictionary project was a separate volume, Gender in Scottish History since 1700, which examined the role that gender played in Scottish history, although due to the expertise of the contributors the book focused on the last three centuries, while the Dictionary itself extended back two millennia. ${ }^{18}$

Edinburgh University Press, which was actively encouraging and publishing the new Scottish histories emerging in the post-1999 period, was very open to the proposal and commissioned The BDSW in 2002. A board of four-Sue Innes, Siân Reynolds, and Elizabeth Ewan as academic editors and Rose Pipes as managing editor-was created and began work, applying for funding, establishing a board of advisors from various fields to help identify potential subjects and contributors, and

16 Breitenbach, 'Curiously Rare', 88-89.

17 For example, Helen Archdale or Lady Isobel Barnett in Hartley, A Historical Dictionary of British Women, 17, 34.

18 Lynn Abrams, Eleanor Gordon, Deborah Simonton, and Eileen Janes Yeo, eds, Gender in Scottish History Since 1700 (Edinburgh: Edinburgh University Press, 2006). doi.org/10.3366/edinburgh/ 9780748617609.001 .0001 . 
commissioning entries. ${ }^{19}$ The press had envisioned a book of about 100 entries of roughly 1,000 words each, with about 10 to 20 authors. However, early on, as more and more suggestions for women to include were received, the decision was taken to privilege broad coverage over long entries. The final book has about 850 individual entries and includes material on about 1,000 women as there are co-subjects in a number of entries, as well as some group entries. The dictionary involved the work of 270 contributors, and ranged from the earliest times to 2004 . The entries vary in length from 150 to 800 words, and each has a short bibliography of sources intended to encourage further research on the subject.

Although there was no current Scottish national project underway, there were some models from the past. As in England, Scottish biographical dictionaries can be traced back to the seventeenth century with Thomas Dempster's 1627 Latin Historia ecclesiastica gentis Scotorum, which included everyone identified as Scoti (Scots). ${ }^{20}$ Since Scoti also meant Irish in the Middle Ages, many of the entries in Dempster's work would later find a place in the Dictionary of Irish Biography. Further collective biographies in the English language followed in the eighteenth century, including George Mackenzie's The Lives and Characters of the Most Eminent Writers of the Scots Nation (1708-22). The first national biographical dictionary, Thomas Stark's Biographica Scotica, appeared in 1805. The nineteenth century was dominated by the work of Robert Chambers, who published the first of many editions of $A$ Biographical Dictionary of Eminent Scotsmen in $1835 .{ }^{21}$ The most recent biographical dictionary for Scotland was produced by Rosemary Goring in 1992, with about 2,300 entries, although over 20 per cent of the subjects, including almost 40 per cent of the women, were still alive at the time of publication. ${ }^{22}$

19 Sadly, Sue Innes, the Dictionary's most indefatigable and enthusiastic proponent, died in 2005 before The $B D S W$ was published. Her work has been carried on by Jane Rendall who is now one of the editors of the second edition.

20 (Bologna, 1627). As can be seen by the use of the term 'ecclesiastical history', Dempster was mainly concerned with demonstrating the Scottish contributions to the Catholic Church. For the tradition in England, see Thomas, Changing Conceptions of National Biography, 2-11.

21 Robert Chambers, A Biographical Dictionary of Eminent Scotsmen (Glasgow: Blackie and Son, 1835). For more detail on the history of biographical dictionaries in Scotland, see Tristram Clarke, 'Paper Monuments: Collecting the Lives of Scots', in The Scottish Nation: Identity and History: Essays in Honour of William Ferguson, ed. Alexander Murdoch (Edinburgh: John Donald, 2007), 18-38.

22 Rosemary Goring, ed., Chambers Scottish Biographical Dictionary (London: Chambers, 1992). 
Women featured only sporadically in most of these works. The 1875 revised edition of Chambers's Biographical Dictionary of Eminent Scotsmen was described as having 'biographies and engraved portraits of Scotsmen and some women' (my emphasis). ${ }^{23}$ There were 14 women (although this was an improvement on the first edition which had nine). Recent more popular biographical projects have not done much better. In 2002 a newspaper listing of the 'Top 100 Scots' included three women. ${ }^{24}$ A popular book, Bill Fletcher's Book of Famous Scots (1995), had no women at all. The author was at least aware of the issue but explained that 'there are no women in our lists' because Scottish schooling had been 'entirely concentrated on the education of male children'. ${ }^{25}$ Women's historians may have appreciated the unintended irony of such a statement as the first conference of the Scottish Women's History Network, held the year before the book's publication, focused on the history of women's education. ${ }^{26}$

As in other countries, there was in Scotland a tradition of collective biographies, and these included some that focused on women. James Anderson's The Ladies of the Covenant: Memoirs of Distinguished Female Characters, Embracing the Period of the Covenant and the Persecution (1880) was, as its title emphasised, a celebration of female religious heroines of the seventeenth century. ${ }^{27}$ Harry Graham covered a wider range of women in his A Group of Scottish Women (1908), while Eunice Murray (herself a subject in The BDSW) produced three collective biographies which concentrated mainly or entirely on women. ${ }^{28}$ This tradition has continued, with a collective biography of 10 nineteenth- and twentiethcentury Scottish women being published in the same year as The BDSW itself. ${ }^{29}$

23 Robert Chambers, A Biographical Dictionary of Eminent Scotsmen (London: Blackie and Son, 1875).

24 '100 Greatest Scots', Sunday Mail (Glasgow), 2 April 2002, 3-15.

25 Bill Fletcher, Baxter's Book of Famous Scots Who Changed the World (Dalkeith: Lang Syne, 1995), 15 .

26 McDermid, 'No Longer Curiously Rare', 390.

27 James Anderson, The Ladies of the Covenant: Memoirs of Distinguished Female Characters, Embracing the Period of the Covenant and the Persecution (New York: A. C. Armstrong, 1880).

28 H. J. C. Graham, A Group of Scottish Women (London: Methuen, 1908); Eunice Murray, Scottish Women of Bygone Days (Glasgow: Gowans and Gray, 1930); A Gallery of Scottish Women (London and Glasgow: Gowans and Gray, 1935); Scottish Homespun (London: Blackie and Son, 1947). She was also the first Scottish woman to stand for parliament.

29 William W. J. Knox, Lives of Scottish Women: Women and Scottish Society, 1800-1980 (Edinburgh: Edinburgh University Press, 2006). doi.org/10.3366/edinburgh/9780748624096.001.0001. 
Most of the Scottish precursors to The $B D S W$ were single-authored or privately financed. The new project with its many collaborators and ambitious reach required some funding from outside sources. A small amount came from the Scottish Government's Equality Unit, but most came from a private trust, The Strathmartine Trust, which funds projects in Scottish history. With the help of a number of other small grants as well as some initial funding from the press itself, we produced the dictionary with about $£ 25,000$ of funding (about AU\$50,000). This allowed us to employ a database person and a research assistant, include 60 images, and make extremely modest payments to those contributors who were unwaged, primarily postgraduate students and independent researchers. Mostly, however, The $B D S W$ was funded by the unpaid time volunteered by the many contributors, advisors, and editors. As we were working on this project between 2002 and 2005, we sometimes cast envious eyes at the $O D N B$ with its multimillion pound budget. ${ }^{30}$ As became obvious during the conference on which this volume is based, however, the $O D N B$ financial situation is the exception rather than the rule for national biographical dictionaries.

While the funding situation created and continues to create obvious challenges, there are some advantages. Tom Griffiths has noted the 'foundation vision of collaborative scholarship', which underlay the beginnings of the Australian Dictionary of Biography $(A D B) .{ }^{31}$ One of the most rewarding aspects of editing The $B D S W$, and one which is undoubtedly shared with editors of other biographical dictionaries, was the joy of working in a genuinely collaborative enterprise in which every participant was thoroughly committed to the goals of the project. In one respect, this commitment was especially important on the part of our academic contributors, as the world of the Research Assessment Exercise (now the REF-Research Excellence Framework) that dominates university research in the United Kingdom is not conducive to such activities. Fortunately, three of the editors also worked outside the United Kingdom university system and were not affected by this, while the

30 As editors, we wish to acknowledge the generous cooperation of the $O D N B$ in agreeing that some of their contributors who had written on Scottish women should be free to also contribute a shorter biography to The $B D S W$. About 400 women appear in both, although in many cases the two articles on an individual woman are written by different authors.

31 Tom Griffiths, 'Foreword', in The ADB's Story, eds Melanie Nolan and Christine Fernon (Canberra: ANU E Press, 2013), xi. 
fourth would shortly retire. Some national biographical dictionaries have had a university home; The BDSW has not, being housed on computer databases and in the editors' homes.

The $B D S W$ was published in 2006 , along with its companion volume Gender in Scottish History since 1700, which demonstrated how considering gender could revise standard interpretations of Scottish history. It was well received and reviewed, enjoyed considerable media coverage in Scotland, was mentioned in the Scottish Parliament, and even made the top of the Blackwell/Scotland on Sunday List of Scottish Non-Fiction in July 2007 when the paperback edition came out. ${ }^{32}$ It has been one of Edinburgh University Press's top-selling reference books, selling well enough that the press was interested in commissioning a revised and expanded volume. The New Biographical Dictionary of Scottish Women was published in autumn 2018, marking the centenary of the first grant of suffrage to women in the United Kingdom. The last decade has demonstrated some of the impact that a wide-ranging women's biographical dictionary can have in helping to shape approaches to a nation's history at various levels.

While The BDSW has become a useful tool for academic research, much of its influence has been at a more grassroots level and on Scotland's younger citizens. One particularly rewarding and enduring result has been the Memorials of Women project, which was initially carried out with the Girl Guides in Scotland. This involved finding memorials to women in the local community and contributing this information to a website, which is still ongoing. ${ }^{33}$ Most memorials appear as plaques or in other forms rather than as statues-in Edinburgh there are at present more statues of animals than there are of women. ${ }^{34}$ Of particular importance to future generations has been the interest of the Scottish education authorities. Scottish history and culture were largely neglected in primary and secondary schools for much of the twentieth century. In the last few years there has been an increasing effort to expose elementary and secondary

32 'The Buzz', Scotland on Sunday, 1 July 2007, accessed 1 August 2017, www.scotsman.com/ lifestyle/culture/books/the-buzz-1-1420570.

33 'Mapping Memorials to Women in Scotland', Glasgow Women's Library and Women's History Scotland with support from Girlguiding Scotland, 2010, accessed 12 December 2016, womenofscotland.org.uk.

34 Dani Garivalli, 'Where Are the Statues of Scots Women?', Scotsman, 23 January 2016, accessed 1 August 2017, www.scotsman.com/news/where-are-the-statues-of-scots-women-1-4009631; Fiona Pringle, 'Campaign Launched to Salute Edinburgh's Greatest Women', Edinburgh Evening News, 10 April 2017, accessed 1 August 2017, www.edinburghnews.scotsman.com/our-region/edinburgh/ campaign-launched-to-salute-edinburgh-s-greatest-women-1-4415842. 
students to the history, languages, and literatures of their own country. Learning and Teaching Scotland commissioned a project to increase the coverage of women in its schoolteaching resources; as a result it is hoped that the history of Scottish women will be seen as a natural part of the nation's history. ${ }^{35}$

In other initiatives, there have been a number of Women's History walks established, and some books which have provided more detailed entries on women from a particular region. ${ }^{36}$ The BDSW has also been used as a primary source of information for several public exhibitions on Scottish women, including artists and suffragists. ${ }^{37}$ It is increasingly being used for websites, including the much-debated Wikipedia, and on sites which focus on Scottish history or women, or women in history. ${ }^{38}$ Moreover, several of the contributors have gone on to write more extensive studies of their subjects, contributing to the expansion of women's and gender history in Scotland in the last decade. Other women have been the subjects of more extensive treatments by other writers. ${ }^{39}$ The last stocktaking of the state of the Scottish historical field at a conference in 2010 included a paper specifically on gender. ${ }^{40}$ The published version provided a synthesis of the last two decades of research, and highlighted 'the increasing scope and sophistication of the body of work accumulating in Scottish gender history, distinctive by its application of emergent and established theoretical approaches, notably poststructuralism, oral history, spatial history, the history of everyday life and micro-history', but also pointed out that there is still much work to be done. ${ }^{41}$

35 The resource, Scotland's History, became less accessible when Learning and Teaching Scotland became Education Scotland in 2010, but can be found at www.sath.org.uk/edscot/www. educationscotland.gov.uk/higherscottishhistory/index-2.html, accessed 5 August 2017.

36 Susan Bennett, Mary Byatt, Jenny Main, Anne Oliver, and Jenny Trythall, eds, Women of Moray (Edinburgh: Luath Press, 2014); Mary Henderson, Dundee Women's Trail (Dundee: Dundee Women's Trail, 2008), available at www.dundeewomenstrail.org.uk.

37 Edinburgh, Scottish National Portrait Gallery, 'Out of the Shadows: Women of NineteenthCentury Scotland' from 2011; Edinburgh, Scottish National Gallery of Modern Art, 'Modern Scottish Women: Painters and Sculptors 1885-1965', 2015-16.

38 For example, 'Undiscovered Scotland', accessed 4 August 2017, www.undiscoveredscotland. co.uk/usbiography/index.html.

39 For example, Christian Fletcher in Jimmy Powdrell Campbell, The Scottish Crown Jewels and the Minister's Wife (Stroud: Tempus, 2007); and Jennifer Morag Henderson, A Life: Josephine Tey (Dingwall: Sandstone Press, 2015).

40 Revised versions of the papers were published in Scottish Historical Review 92 (Supplement) (2013) and included Katie Barclay, Tanya Cheadle, and Eleanor Gordon, 'The State of Scottish History: Gender', 83-107. doi.org/10.3366/shr.2013.0169.

41 Barclay, Cheadle and Gordon, 'State of Scottish History: Gender', 106-7. 


\section{Towards The New BDSW: Issues Arising}

So where are we in 2019? For the first edition, we had proposed the possibility of an online version, but the publisher was not keen on the idea. Indeed, we lost out on some potential funding sources because funding agencies thought it should be online. However, when the press decided to commission The New BDSW in 2015, it was for a print version only. There are a number of reasons for this, especially as funding sources get tighter for national dictionary projects. University presses are under pressure to produce profits and an open-access online dictionary will not do that in and of itself. Many English-language national biographical dictionaries, such as the $O D N B$, and the ones for the United States and for Ireland are available on a subscription basis, although those of Australia, New Zealand, Canada, and Wales are freely available. Unfortunately, the cessation of funding left the New Zealand dictionary for some years without sufficient resources to be kept up to date (the project is now being revived), ${ }^{42}$ while the Welsh one is only minimally searchable, presumably due to funding constraints. There are expectations that an online dictionary will be updated on a regular basis, and there are costs associated with that. In our case, we have the additional potential funding issue that our dictionary is not truly national in the traditional sense, as it only covers half the population-this is discussed further below.

What does the second edition look like? The press allowed us an extra 65,000 words with which to correct errors, update original articles where more work had been done on the subject since 2004, and add new women, including those who died in the years 2004-16. The initial funding was $£ 3,000$ (AU\$6,000), meaning that we were even more reliant than last time on voluntary labour, although another $£ 1,500$ (AU\$3,000) was secured from other sources, including the Strathmartine Trust. As we began work, we found ourselves revisiting some of the main issues which came up in the past, and which will resonate with editors of other biographical dictionaries, as well as historians in general. Because of being restricted at this time to a print publication, however, we had to make some hard decisions which might not face those whose dictionaries are now online.

42 See the chapter by Phillips in this collection. 
One of the most important aspects of biographical dictionaries is deciding on the principles of selection of subjects. Probably the first question which occurs to readers when looking at a dictionary of Scottish women is what defines 'Scottishness' - this issue of identity is of course addressed by all editors of biographical dictionaries, and is of central importance to nations themselves. There is a certain irony that none of the present editors was born in Scotland and only two live there, although on the other hand it does reflect an international interest in the topic.

How have the editors made decisions on who is Scottish? Many biographical dictionaries, facing less severe length restrictions, have been very inclusive. The $A D B$, for example, felt that its criteria should evolve organically. ${ }^{43}$ Because The BDSW consisted in its entirety of one print volume, firm decisions about inclusion had to be made at the very beginning of the project. For example, should women of Scottish descent living elsewhere be included? Many such people would self-identify as 'Scottish'. The $O D N B$ has included many diaspora figures, such as Nellie McClung, a leader of the suffrage movement in Canada, who had an Irish father and a Scottish mother, but was born and spent her whole life in Canada. What of those who have no close connection to the country? The $A D B$, for example, includes those who have never been to Australia but have had some impact on the country. The Welsh Dictionary has some similar entries.

To be included in The BDSW, a woman had to have been born in Scotland, lived in Scotland for an appreciable period, or, if only there for a short time, to have influenced some aspect of Scottish national life. Being born to Scottish parents abroad was not enough by itself. It is noticeable that in The New BDSW because of the pressure of new entries and the continued constraints and limits of a print edition, we have been stricter about the time in Scotland aspect-if a potential subject was born in Scotland but spent most of her life somewhere else, she was less likely to be included than was the case in the earlier edition. In the first edition we attempted to provide at least some representation of Scottish-born women in the diaspora. We have been unable to continue this in the second edition, which is a matter for regret. Possibly if The New BDSW eventually goes online, it could collaborate with national biographical dictionaries of other countries to link to such women or to supplement entries with more material on the Scottish part of their lives.

43 Nolan, "Insufficiently Engineered"', 21-22. 
Two characteristics of the first edition have not been repeated in the entries which make up the additional material in The New BDSW. The first edition considered it crucial to give space to 'representative' women, 'women who were not remotely famous, but whose story in some way represented areas of Scottish life or economy, where women were generally present but rarely individually recorded'. ${ }^{44}$ This is an approach taken by many biographical dictionaries in recent years. ${ }^{45}$ The issue of representative people can be controversial- to what extent is any one individual ever representative? Due to lack of space, we have relied on the coverage provided by entries from the first edition for representative women. We also included some mythical women in The BDSW, either because they were central to ideas about Scottish identity, or because they had become so well known in popular culture and history as to be considered real. All of our new subjects did actually exist.

The additional space has afforded us 181 new entries, with another 99 women as 'co-subjects' who appear within entries on other women. One of the constraints of remaining as a print edition is that final decisions had to be made about who to include before publication as others cannot be added online later. This pressure has been increased by the decision to keep all the subjects from the original volume. Some inclusion decisions reflect the publisher's concerns to make the enterprise profitable, and indeed for us to make the book attractive to potential readers, as it needs to sell. This has led to the inclusion of women who have died very recently such as the novelist Muriel Spark, author of The Prime of Miss Jean Brodie, or Hollywood star Deborah Kerr, as including women well known in the last 20 years helps increase the attractiveness of the dictionary to the potential buying public. This means that we have included women who have died in 2016. The $O D N B$ seems to have a four-year cut-off, while the $A D B$ is now working on people who died in the 1990s, although the related Obituaries Australia site provides more recent biographies. ${ }^{46}$ The Irish and Welsh dictionaries do include people who have died in the last few years. Lack of historical perspective, though, can raise issues about how they are to be represented in a biographical dictionary, and it is likely that these entries would be considerably revised in future editions.

44 'Introduction', The BDSW, xxxi.

45 Thomas, Changing Conceptions, 44-45. See, for example, Macdonald, Penfold, and Williams,

The Book of New Zealand Women/Ko Kui Ma Te Kaupapa, viii.

46 'Obituaries Australia', National Centre of Biography, The Australian National University, oa.anu.edu.au/. 
Which women have been selected this time? There is no longer the urgency to make the case that women in Scotland do have a history, as the first edition contributed to this (at least we hope it has), so this has led to some changes in how decisions were made about who to include. With an additional decade of research on women in Scottish history, The New $B D S W$ is focusing on enhancing a body of established work, rather than creating it from scratch.

One issue which arose from the 2006 book is that of coverage, both of regions and of certain thematic categories. It was, perhaps not surprisingly given the state of research at the time, dominated by women connected with Edinburgh, Aberdeen, and Glasgow. We were particularly sensitive to the overrepresentation of women from the capital and for this reason requested that the press not entitle the volume The Edinburgh Biographical Dictionary of Scottish Women. This concentration is characteristic of The New BDSW as well, due to population distribution and other factors, but we have made a concerted effort to bring more coverage to other geographical areas. So, for example, a Shetland poet from the Northern Isles is more likely to be included than an Edinburgh poet of similar status. Writers also tended to be overrepresented in The BDSW, a not uncommon problem in national biographical dictionaries, and we have been more restrictive about including them among our new entries. Efforts have been made to compensate for categories that were underrepresented previously; there is a higher proportion of sportswomen and scientists. Partly as a result of the pressure to include women who have died recently, the heavy concentration on the last two centuries has increased, as only a few earlier women have been added.

One aspect of the first edition which we felt was very important was the identification of networks of women. When a woman mentioned in one entry was the subject of another entry, an asterisk indicated this. But this has its limitations. For example, if one entry mentions a woman who is the subject of another entry, that second entry may not mention the first woman, so the connection is only indicated in one place. The number of links between women in the bodies of the entries has now been expanded considerably. But somewhat ironically, our project to bring to attention women hidden from history managed to hide still other women from readers, as co-subjects could only be found in entries on other women, not in alphabetical order. The New BDSW makes such women and the connections between them and other women much more visible. There is now an alphabetical list of co-subjects so that readers can see at a glance who 
is included among them. We have also increased the number of thematic categories in the index, breaking down a number of broad categories into more specific ones (for example, adding theology as a separate category instead of including it under the broader category of religion) so that readers can see at a glance the women in a variety of fields.

\section{Women's Biographical Dictionaries and Biographies of Nations}

Biographical dictionaries of women can raise questions which are of wider interest to nations, and historians and biographers. For example, what happens to one's sense of national identity when moving to a place if it is not necessarily one's personal choice to move there? Many of the women included in The BDSW, especially those from earlier periods, either moved to or moved from Scotland because of marriage, rather than due to any real desire to change their place of residence. Despite this, many of them made a success of their lives in the new culture in which they found themselves, an example that is becoming increasingly important in an ever more cosmopolitan society. In a post-Brexit United Kingdom, national biographical dictionaries can play an important role in demonstrating how nations are built up not only by those whose families have lived there for generations but also by those who have arrived more recently. The present Scottish Government, in response to the majority of Scots having voted to remain in the European Union, has been making a point of defining the country increasingly as 'European' in contrast to its southern neighbours - the stories of many of its historic women could be called upon in support of this imagining of the country.

There are also issues of personal identity, raised by the fact that married women for most of history became subsumed into the legal identity and status of their husbands. One interesting aspect of Scottish life is that until the later eighteenth century most married women retained their natal family name on marriage. The change in practice has led to some practical problems with nomenclature with which other editors will be familiar. Under what name should a woman be entered: her birth name, her married name, her second married name? It can be an awkward issue when the natural reaction of modern editors is to identify women for who they are themselves, rather than as spouses. However, that is imposing modern standards on them. The choice in the case of The BDSW has 
been to use the surname by which the woman was most commonly known, but to indicate the other names immediately afterwards. Other biographical dictionaries follow a range of practices. The Dictionary of Canadian Biography/Dictionnaire biographique du Canada $(D C B / D B C)$, for example, uses the birth names of some women who also appear in The $B D S W$ under their married ones-this is another argument for making links between different dictionaries to address such issues.

The New BDSW with its more modern focus reflects the increasing practice of women to retain their birth surnames, to the great relief of biographical dictionary editors. The question of how to treat Gaelic names with their patronymics is something that is shared with the Dictionary of Irish Biography. ${ }^{47}$ Our choice to follow Gaelic practice in The BDSW and enter women by their forenames rather than by patronymics resulted in one reviewer criticising the first edition for not including Gaelic women, as he had not realised how they had been entered. ${ }^{48}$ Greater cross-referencing in The New BDSW should address this, but, as this example indicates, nomenclature is more than a technical issue; it raises issues of historical visibility as well. Linguistic factors also raise issues of visibility and identity. Scotland is a multilingual society: should Gaelic women at the least have Gaelic-language entries, as well as or instead of English-language ones, or would such a practice obscure them further?

Women's biographical dictionaries raise the issue of what it has meant to be a woman in a society in the past and how that has changed over time. All biographical dictionaries reflect changes in society over time, of course, but the rapidly changing and still altering position of women perhaps makes such changes even more visible. With recent changes in sexual mores such as the increasing legal and cultural acceptance of gay marriage and LGBTQI* rights, old categories are being broken down. For example, one of the people included in The New BDSW was identified at birth as a girl, but had the birth certificate altered later in life to indicate the sex as male. Such examples raise questions about gender binaries and how to deal with those who do not fit neatly into either female or male categories, as well as the language which is used to describe them.

47 See chapter by O'Riordan in this volume.

48 Murray Pittock, review of The BDSW, Scottish Studies Review 7, no. 2 (Autumn 2006): 109. 
From the very beginning of the project, one guiding principle was that entries should be about lives, not careers. Practitioners of feminist biography have made clear 'the complex interplay between the elements in women's lives, where the common distinction between "life" and "work" rarely fits. ${ }^{49}$ Moreover, women's 'careers' rarely followed a straightforward trajectory. This became especially clear to the editors when it was decided to create a thematic index for The BDSW. How does one categorise a subject such as Clementina Stirling Graham, impersonator, author, translator, and beekeeper, or women such as Margaret Oliphant, who turned from writing for pleasure to writing as a necessity in order to support her family? The realities of many subjects' lives break down any artificial barriers between private and public spheres, as well as expanding the definition of the political. These insights, common to feminist biography and history, can inform all entries in biographical dictionaries, not just entries on women. ${ }^{50}$

Finally, in terms of creating new 'biographies of nations', Scotland is in a somewhat unusual position, partly due to its constitutional position within the United Kingdom (at least at present). There has been no government or university-sponsored initiative to produce a Scottish dictionary of national biography in recent times. This is probably because the $O D N B$ has done such good work in including the latest in Scottish biographical research. But if biographical dictionaries really are biographies of nations, it could be argued that Scotland should also have a more recent separate one, as does Wales. Indeed, depending on the longterm effects of Brexit, it is even possible that Scotland might become an independent nation once more.

What is the role of a women's biographical dictionary when there is no national 'biography of the nation'? Brian Harrison, the editor of the $O D N B$ in its later stages, commented on how 'Serendipity and practicalities ... inevitably influenced the final selection-a point which needs to be remembered by anyone embarking upon a quantitative survey of the Dictionary's contents'. ${ }^{51}$ However, such surveys can give a rough

49 Williams, Macdonald, and Penfold, The Book of New Zealand Women/Ko Kui Ma Te Kaupapa, vii. 50 Susan Ware, 'Writing Women's Lives: One Historian's Perspective', Journal of Interdisciplinary History 40, no. 3 (Winter 2010): 417, 420-22. doi.org/10.1162/jinh.2010.40.3.413; Robert Rotberg, 'Biography and Historiography: Mutual Evidentiary and Interdisciplinary Considerations', Journal of Interdisciplinary History 40, no. 3 (Winter 2010): 322. doi.org/10.1162/jinh.2010.40.3.305.

51 Brian Harrison, 'Introduction', in Oxford Dictionary of National Biography, eds H. C. G. Matthew and Brian Harrison, vol. 1, Aaron-Amory (Oxford: Oxford University Press, 2004), ix. 
impression. National biographical dictionaries elsewhere are working hard to increase the coverage of women-at present, entries on women make up about 10 per cent of the $O D N B, 12$ per cent of the $A D B$, and 6 per cent of the $D C B / D B C .52$ This raises an interesting possibility. With proportions such as these for one-half of the population in other national biographical dictionaries, since The New BDSW has about 1,000 entries covering the female half of the nation's population, to make it a truly national biographical dictionary should only require the addition of about 110 men.

52 The first series of the $D N B$ along with the three 1901 supplements had 998 entries on women out of a total of 28,201 subjects. Gillian Fenwick, Women and the Dictionary of National Biography: A Guide to DNB Volumes 1885-1985 and Missing Persons (Aldershot: Scolar Press, 1994), 6. In the $O D N B$ as published in 2004, there were 5,627 women among the 54,922 lives, raising the percentage of women from 3.5 per cent to 10 per cent. Harrison, 'Introduction', xvii. In the $A D B$ women's entries number 1,589 out of 12,899 (12 per cent). Australian Dictionary of Biography, faceted browse, accessed 1 August 2017, adb.anu.edu.au/facets/. In the $D C B / D B C$, 539 out of 8,663 biographies are of women. DCB search page, accessed 1 August 2017, www.biographi.ca/en/search.php. The percentage has risen from 6 per cent in the earliest volume to 15 per cent in the volume covering 1921-30. 'Women in the Dictionary of Canadian Biography/Dictionnaire biographique du Canada (DCB/DBC)', accessed 1 August 2017, www.biographi.ca/en/theme_women.html. 
This text is taken from 'True Biographies of Nations?': The Cultural Journeys of Dictionaries of National Biography, edited by Karen Fox, published 2019 by ANU Press, The Australian National University, Canberra, Australia.

doi.org/10.22459/TBN.2019.07 